\title{
ON THE DATES OF PUBLICATION OF THE EARLY VOLUMES OF THE SOCIETY'S PROCEEDINGS.
}

\section{By J. J. Fletcher.}

The first twenty-eight Parts of the Society's Proceedingsconstituting Vols. i.-vii. of the First Series (for the years 18751882) - offer no more definite indication of the several dates of publication than is afforded by a notice of the year of issue at the foot of the front page of the paper covers, or on the titlepage included in the fourth and concluding Part of each Volume. Unless specially instructed to the contrary, bookbinders seem habitually to discard the covers when binding. A number of copies of Vols. i.-iv., bound at Sir W. Macleay's expense, so treated, have passed into circulation under the Society's auspices. In regard to these, and others so dealt with, it should be borne in mind that the year indicated on the title-page is usually that in which the fourth and last Part only of the Volume was issued: or if not so, the coincidence is accidental.

The first twenty-six of the Parts in question were issued prior to the Garden Palace Fire. As the Society's official books and records were completely destroyed therein, no information whatever about these early Parts is forthcoming from this source. Eleven consecutive Parts commencing with Part 2 of Vol. i., were printed by two firms which subsequently retired altogether from business, the establishment of one of them having been completely burnt out; so that no particulars from the publishers are obtainable, and I have only the dates of receipt kindly supplied by the Librarians of the Public Library and Royal Society of N. S. Wales to go by.

Occasionally there arise questions of priority in the description of species dealt with in these Volumes; and requests for authoritative information as to dates of publication are from time to time received. 
It seemed advisable, therefore, that the effort should be made, once for all, to ascertain if possible the dates of publication of the first twenty-six Parts with a view to their publication. On applying to the Librarians of the Public Library, Sydney, and the Royal Society of New South Wales, I was most kindly furnished with almost complete lists of the dates of their receipt of the various Parts - which are approximately those of publication. Messrs. F. Cunninghame \& Co., who printed Part 1, very obligingly referred to their books, and supplied the requisite information about this Part. Mr. F. White, who printed Vols. iv.-vii., most courteously provided me with a list of the dates of delivery to the Society of the sixteen Parts comprised in these Volumes. From the data so supplied, the list-as approximately correct as it is now possible to make it-given overleaf has been compiled.

One or two other matters may also be noted.

The first Volume is exceptional in that it comprises the Proceedings of two years-Part 1 constitutes the Proceedings for 1875: Parts 2-4 the Proceedings for 1876. In the separate copies of Part 1 as issued, was inserted a slip-which is missing in all the bound Volumes I have seen-setting forth that-

"The first 20 pages of this Part were printed and circulated ten months ago. They have now been re-printed in order to make the Part complete."

The sixteen consecutive Parts, commencing with Vol. viii., and ending with Vol. i. (Second Series), have the dates of issue on the paper covers, but there only. If the covers have not been preserved in binding all clue to dates is lost in bound volumes. They are accordingly included in the list.

Commencing with Vol. ii. (Second Series), not only is the date given on the cover of each Part, but it is repeated at the head of the lists of the Contents of the four Parts comprised in each Volume, supplied along with the title-page and Index in the concluding Part thereof. No room for doubt, therefore, can arise in connection with these and future Parts :- 
First Series.

Vol. i. Part 1 (pp. 1-20 only)-Issued April 27th 1875.

$$
\begin{aligned}
& 1 \text { (pp. 1-96) } \\
& 2 \text { (pp. 97-168) } \\
& 3 \text { (pp. 169-282) } \\
& 4 \text { (pp. 283-419) }
\end{aligned}
$$

Vol. ii. Part 1 (pp. 1-122)

$$
\begin{aligned}
& 2 \text { (pp. 123-217) } \\
& 3 \text { (pp. 218-288) } \\
& 4 \text { (pp. 289-401) }
\end{aligned}
$$

Vol. iii. Part 1 (pp. 1-76)

2 (pp. 77-161)

3 (pp. 161-305)

4 (pp. 306-443)

Vol. iv. Part 1 (pp. 1-116)

2 (pp. 117-244)

3 (pp. 245-387)

4 (pp. 387-492)

Vol. v. Part 1 (pp. 1-105)

2 (pp. 106-272)

3 (pp. 272-458)

4 (pp. 459-652)

Vol. vi. Part 1 (pp. 1-170)

2 (pp. 170-408)

3 (pp. 409-711)

4 (pp. 712-872)

Vol. vii. Part 1 (pp. 1-135)

2 (pp. 135-304)

3 (pp. 303-404)

4 (pp. 405-684)
„* February 1876 .

"*July 1876.

„* * February 1877.

", March 1877.

„ *July 1877.

„, *January 1878.

"*May 1878.

„, *June 1878.

„, *September 1878.

„ *December 1878.

", Dece

" "Nay 1879.

„June 16th 1879 .

" October 6th 1879.

" December 1st 1879.

" May 1880.

" August 1880.

" November 22nd 1880.

„ February 1881.

" May 20th 1881.

, July 1881.

„ September 12th 1881.

" December 1881.

" March 20th 1882.

„ May 23rd 1882.

", August 1882.

" October 28th 1882.

„April 1883.

* Dates of receipt, or more correctly, dates of registration. As at this time the publications do not seem to have been always delivered as punctually as they are now, it is not improbable that some of the dates given are really as much as one month or even longer behind time. 


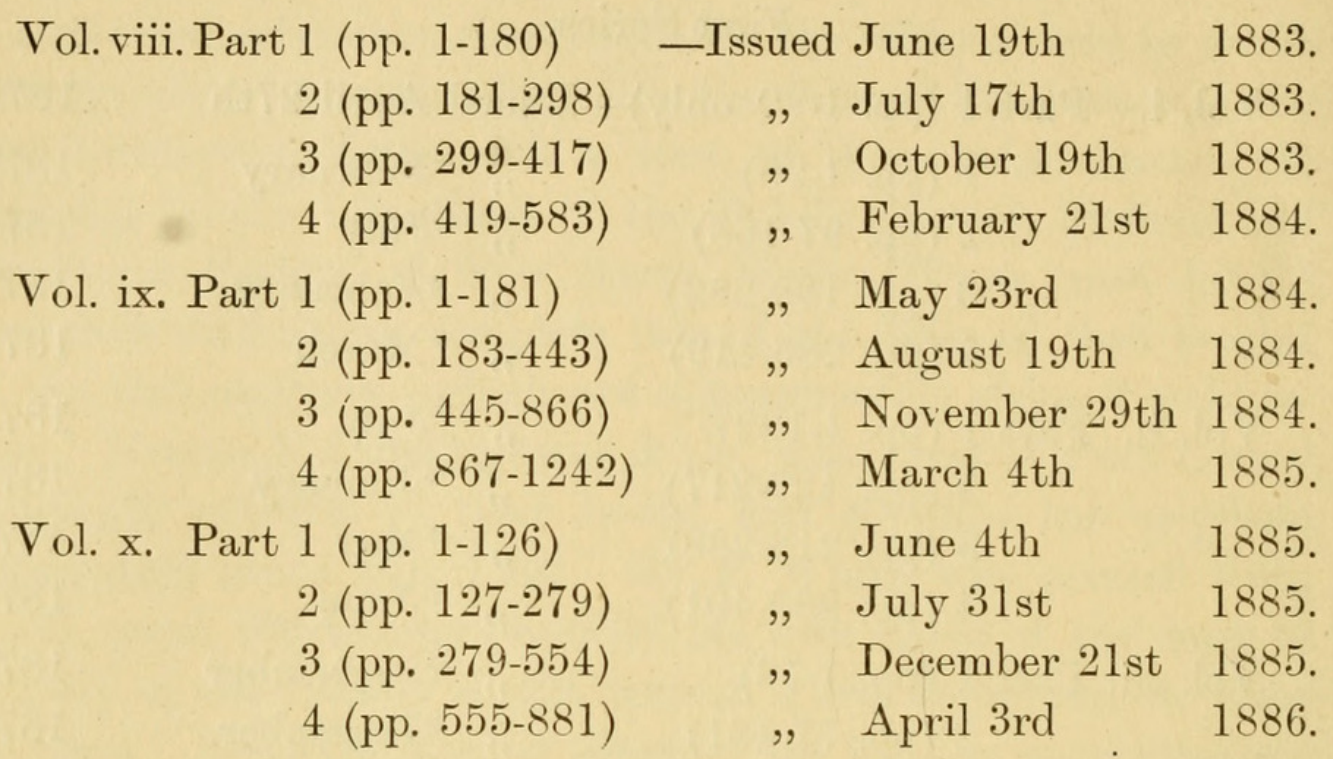

Second Series.

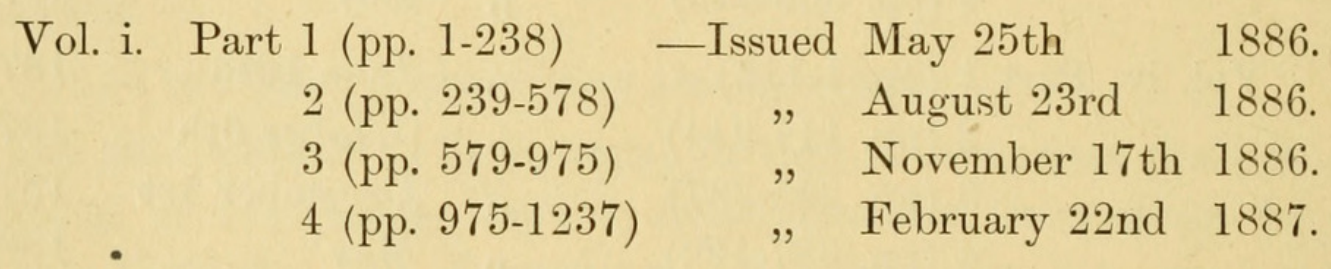

\section{DESCRIPTION OF A TREE CREEPER PRESUMABLY NEW.}

By C. W. De Vis, M.A., Corr. Mem.

Unknown to the author, the same species had been shortly before described by Mr. North in the Ibis (July, 1895). The paper was therefore withdrawn. 


\section{$2 \mathrm{BHL}$ Biodiversity Heritage Library}

Fletcher, J. J. 1896. "On the dates of publication of the early volumes of the Society's Proceedings." Proceedings of the Linnean Society of New South Wales 10, 533-536. https://doi.org/10.5962/bhl.part.24365.

View This Item Online: https://www.biodiversitylibrary.org/item/30097

DOI: https://doi.org/10.5962/bhl.part.24365

Permalink: https://www.biodiversitylibrary.org/partpdf/24365

\section{Holding Institution}

MBLWHOI Library

\section{Sponsored by}

MBLWHOI Library

\section{Copyright \& Reuse}

Copyright Status: NOT_IN_COPYRIGHT

This document was created from content at the Biodiversity Heritage Library, the world's largest open access digital library for biodiversity literature and archives. Visit BHL at https://www.biodiversitylibrary.org. 